\title{
NATIONAL SELF-AWARENESS: THE DISCOVERY OF DESTINY AND BEAUTY
}

\author{
Minhojiddin Mirzo Khodjimatov \\ Independent researcher of National University of Uzbekistan, \\ Tashkent, Republic of Uzbekistan
}

Article DOI: https://doi.org/10.36713/epra1506

\begin{abstract}
National self-awareness is an event directly related to one's life, destiny. Literature is a force that influences thinking through emotions, shaping a person's characters and outlook. It creates a new artistic world by summing up the call of the heart, the phenomenon of self-awareness with the pain and wonder of the soul.Certainly, the book "My Dagestan" and poetry of the great poet of Dagestan, Rasul Khamzatov and the works of the great Kyrgyz writer Chingiz Aitmatov have given a new impetus to the development of national identity in the works of Uzbek writers. Indeed, every talent gains strength and energy from other unique featured great talents. In this sense, we know how much Rasul Hamzatov enjoyed Oriental poetry at times, in particular, the works of Alisher Navoi. In addition, Amir Timur "Disciplines" of Chingiz Aitmatov, the teachings of Bahauddin Naqshbandi, the works of Alisher Navoiy, the works of the twentieth century Jadid literature, especially the works of Abdulla Kadiri were truly impressed him which contributed to his literary maturity.Therefore, this article tells about the great intimacy and spiritual harmony in the work of the great Uzbek writer Abdulla Kadiri and the great Kyrgyz writer Chingiz Aitmatov. To be more precise, the particularities related to the influence of Kadiri's works on Aitmatov's artistic thinking which influenced on the development of world literature are analyzed.
\end{abstract}

KEY WORDS: Abdulla Kadiri, Bahauddin Naqshband, Chingiz Aitmatov, Dagestan, Jadid literature, writer.

\section{INTRODUCTION}

It is well-known that the feeling of love plays a special role in the self-consciousness of each nation and its adornment. In the Orient, two love-loving hearts can be united by marriage, according to Muslim values. It is said that all beings, the universe, and the angels welcome the covenant of the two beloved hearts. In the Oriental epics, the greatness of human love is again tested by faithfulness, and is strengthened by faithfulness. In many of them, if the heroes see their situation as the verdict of the destiny and fate, the heroes Ra'no and Anvar of "Mehrobdan chayon" (Scorpion from the Chancel), by the first modern novelist in Central Asia, Abdullah Kadiri sought to get out of a difficult situation they faced with unmatched courage and determination for their lifetime, they fought for the right to a happy life, proving that this trial was not destiny and fate. It was in this sense that the work had a revitalizing power.

In the preface to the fourth edition of the "Mehrobdan chayon", academician I.Sultanov says: "Not only have we Uzbeks, but many peoples of our union learned lessons in this regard from Abdullah Kadiri. According to Mukhtar Avezov, a great Kazakh writer and one of the greatest representatives of world literature, A. Kadiri stays as "The Most Outstanding Oriental Soviet Writer" [1], [4].

It should be noted that this new literary interpretation in the work of Abdulla Kadiri has become a peculiar principle in the Oriental literature and has inspired many artists, including then-barelyrecognized the then-young Kyrgyz writer Chingiz Aitmatov.

At first glance the novel by A. Kadiri "Mehrobdan chayon" and the story "Jamila" by $\mathrm{Ch}$. Aitmatov seem to have no shared emotion or spiritual connections. Is it really so? The reader is quick to point out that Rano's immense love and devotion to Anvarmirzo is an indisputable spiritual gulf between Jamila's betrayal for her husband Sadiq who was fighting in the war to win Donyor's love. Comparative analysis of the two works will attempt to shed light on the differing views on the story of Jamila.

Another important aspect of Oriental values is that the more glorious of love, loyalty, and faithfulness, the more the condemnation of unfaithfulness and betrayal of the beloved is. Adultery, that is to say, premarital coition is considered to be the most serious sin. 
Influenced by such great values, many of us have been unable to forgive Jamila in the story of "Jamila" by Ch.Aitmatov for her betrayal to her husband for over 30 years. Because, we did not want to understand her love. According to the famous French writer Louis Aragon, "... How can a young man on the edge of Central Asia, in the second half of the twentieth century, write such a story, and, I swear, the best of love stories in the world?", the comparison of the story with Shakespeare's "Romeo and Juliet" seemed a bit too much for many. There were many scholars and readers who blamed the writer for the "courage" of Jamila, as the one who dishallowed the Oriental values, and the one who abused marriage.

\section{METHODS}

Although famous writers and the Western world were highly acclaimed by the story, at times the writer had to receive serious criticism for the story of "Jamila": "When the story "Jamila" was published, our presentable literary writer immediately stuck to it, remembers the author. - "The story had been ruined in a sectarian meeting, in the eyes of the public ..." [2], [56].

While analyzing the "courage" of heroes of Aitmatov's "Jamila" and Utkir Khashimov's "Ikki eshik orasi" (Between Two Doors) a well-known literary scholar Yuldash Salijonov says: "In fact, this infidelity deserves serious discussion (the statement is ours - M.M). However, the writers behave unbiased in this regard. Chingiz Aitmatov will refer the assessment of Jamila's actions to the storyteller Seit, the people from aul (a little village) and the readers who are directly witnesses to the incident."

Based on Oriental values, as prof. Salijonov said, this adultery is worth serious discussion. The main protagonist of Aitmatov's "Jamila" story betrays her husband, who has been fighting in the war. It is clear that any Orientalist who comes to a hasty conclusion about the work, accuses Jamila of being unfaithful and ill-behaved. What is, in fact, reality?! Well, how did Ch. Aitmatov mange to violate the traditions of Oriental literature on this particular love? Did the French writer Louis Aragon appreciate this work for that reason alone? Who gave Aitmatov the will and strength to do so? Was he really the first in the East to sing such a rebellious love story?

\section{RESULTS AND DISCUSSIONS}

Although Kadiri's first novel "Bygone Days" heroes' destiny and fates end with tragic separation and doom in accordance with the Oriental traditions, the novel "Mehrobdan chayon" takes a completely new approach to the topic of love. Anvar's lover, Ra'no, stands out for her fights with courage, love, and determination for her destiny. Rano does not consider the verdicts of time to be a fate. For the first time in this work, the author raises Rano's courage to a level of stamina and skillfully expresses her courageous struggle for the happiness of not only the Uzbek but also the Eastern girl. This, in turn, had a strong influence on $\mathrm{Ch}$. Aitmatov. The fact that he wrote the first story of his in the same spirit which proves the statement mentioned above.

We have comparative thoughts on the courage and persistence in Rano and Jamila's nature which amazed their admirers, that shows that in writing his story "Jamila" Aitmatov was influenced by the peculiar tradition started by A.Kadiri.

As we read the story thoroughly, we begin to re-grasp meaning, symbols and essence hidden behind each word and line by $\mathrm{Ch}$. Aitmatov. It feels like the curtains covering the words have been removed, and each expression seems to shine through the rays coming from the writer's heart. The reason is that the writer had not committed something sinful as he was blamed for, he had not underestimated a millenium long traditions. He had not mock over marriage.

His heroine did not go through the street of betrayal. As we carefully researched the book, we realized why the author, although not so common in the Kyrgyz, called the girl, the heroine of the work with the name "Jamila" which means beauty. Now let's move on to the comparative analysis of the essence of the works. First of all, how was Jamila and Sodiq's family formed? Let's Read on!

"... She was a daughter of a horseman in the Bakayir aul situated in the outskirts of a mountain, who grew up among the herdsman, from a young age, my brother Sadik was a rider, and one day he could not manage to overtake Jamila in a racing event organized in a grassland for the honor of a horsemen's wedding. I knew that then he was ashamed and kidnapped her" [3], [79].

In the work, along with describing how Jamila gets trapped in the grip of furious Sodiq, the writer also draws the reader's attention to the peculiar determination of Jamila's nature: “Jamila's behavior had some enthusiasm, a masculine personality. She was very enthusiastic about everything, and she never complained that her head and back, like many other brides, were in pain. But she was one of those stubborn women who would not let others to get her fortune, who would never stop arguing and insulting if she had to do" [4], [79].

The men in the aoul, especially the former soldiers who had returned from the front, could not dare to cross the border, though they would joke with Jamila. The reason was that Jamila was used to overreact. The author describes Jamila in such a way that the reader laughs, plays, and jokes with her, but his/her heart always feels not at ease. What would it be like to feel this pity for Jamila and miss her genuine happiness? In the process, the reader will be faced with endless questions as he looks at the sad life hidden in her joy. Did this family have any spiritual or moral foundations? Was this family fortified by a marriage that was agreed upon by both parties? Did Jamila's heart and approval in the making of this family play a 
role? Did anyone consider Jamila's will and wishes? Was Jamila happy with this marriage?

According to Islamic teachings, the family is built to please the Creator and to adorn humanity. In Islamic religion, a special emphasis is placed on marriage, that is, on the consent of both parties.

Now, back to the heroes of the work, Jamila does not receive matchmakers from Sodiq, nor does the consent of hers and her parents are sought. Despite seeming to agree with her fate, there was some sort of anonymous rebellion in the heart of Jamila. It seems that she was as helpless as a bird that had fallen into the eagle's claws against her dreams and happiness, and she appears to be as a flower, as a ray sentenced to die. The author describes this case through the words of Seit: "... I noticed that Jamila was staring at the sunset for a long time. ... Jamila's hands were covering the sun and she was looking at the sun, smiling, looking at it, as if there was a strange sight. "[5], [81].

There was hope and aspiration for tomorrow, a belief for a certain miracle to happen in her stare towards the sunset "as if there was a stunning view". The author describes this situation through the words of Seit: "Jamila was silent for a moment in the setting sun. Then, as if talking to herself, not to me, she said," Would such people understand what was in one's heart? God knows, maybe, there is no such man in the world!" [6], [82].

Through the episode of sunset the author describes how yet another day without a single dream of hers coming true made Jamila feel gloomy from deep down from her heart. She was living her life waiting for a true lover who could understand her heart full of love in the state of unrelatedness to her. She even did not bother to read the letter she received from her husband, to be more exact, did not rush to read it. The reason was that such letters could not light Jamila's dark heart. Why were her eyes faded? Because her dreams had been crushed by the rush of violence. She was condemned to give up the desires of the soul. She was tormented by the fact that she would never live in such an unhappy, unloving, or hopeless life.

It all starts with Jamila coming to the field to work on a daily basis. The chairman got her mother-inlaw agreed. At first the mother-in-law hesitates and then feels at ease as her son Seit and mild-hearted Doniyor, who had returned home from war after getting injured, would be regular companions to her bride. The naive and timid Doniyor was the exact opposite of the bride. Jamila often humiliated and annoyed Doniyor.

The author slowly takes the reader to the world of Doniyor, who, at first glance, seems to be a quiet river, but in the depths of his heart playing waves. Yes, Doniyor had his own inner world. It is clear that the world was more beautiful, more charming, and full of hopes than this world. There was a great love devoted to someone there. Even Doniyor did not know to whom it was meant to be. Therefore, he would enter the world and enjoy it as soon as he could. Even Seit, though a young boy, could feel it. Sometimes his eyebrows were twitching, his eyes were twinkling and his body was filled with energy, and he seemed to leap out of his seat and stretch his arms around his chest to embrace the whole world. In another glance, he would seem just as an exhausted man getting more and more languish." [7], [85]. The reason for this dejection was to wait, wait and wait.

Ch. Aitmatov compares the development of the relationship between Doniyor and Jamila with such vivid images that we are amazed at how naturally the two opposite ends of poles are approaching each other. Every time Jamila and Seit overtake Daniel on the way, leaving him in the dust. Though it is a joke, Doniyor does not say a single word. He gently smiles at the chariot driven by Jamila and Seit passing by him with noise. He looks silently, in the state of joy as if he is content, to Jamila standing up on the cart whipping horses again and again. The writer draws the image of an overindulgent gentleman, at the same time with the heart full of mysterious grief through the single look of his.

Seit feels the beginning of the relationship between Jamila and Doniyor. More precisely, he is the one who sees this love sparkle in Doniyor's eyes, not in Jamila's.

The event of the "big bag" in the storage house is a turning point in the lives of heroes. In this scene, Doniyor's manly pride along with honor, his love which is reflected in his heart is revealed. Several calls of Jamila to Doniyor to throw such a heavy bag to the ground gets in vain, no matter how hard she tries to explain that all of these were just joke, he says "Move over!" and does not throw the bag away. Although Jamila laughs and says some sarcastic words as she follows Doniyor on his way towards the storage house through a hanging wooden corridor on his wounded feet, her laughter gets artificial over time. The call of Jamila "Return Back!" is left unresponded.

The next morning, when the grain was being packed, Jamila picked up the sack and tore it to pieces. And they go back to their normal jobs. The silence between them is also broken by Jamila herself, and she cannot keep silent. It was as if she was trying to entertain and relieve his frustration. On the other hand, there was a special layer of apology, a unique way of seeking for forgiveness. But this plea is not in the form of a plea, but in the vividness and joy of the nature of Jamila.

Jamila, at first, shudders, and then sings out loud with her enthusiastic voice coming from her hot boiling heart. Her song would let people relax. Suddenly, she stops singing and screams at Doniyor: "Hey, you, naive guy, get your voice out!" Are you a man?" -says Jamila, Doniyor stops his chariot and responds: "Sing away, Jamila, I'm all ears." But Jamila is not satisfied with this. She asks a series of sarcastic questions: "Do you really think that others don't want to hear a song?", "Don't sing if you don't want to, look at the way he tries to excuse!", "Hey, Doniyor, have you ever been in love with someone?" Doniyor does not 
respond to her ridiculous funny questions. Jamila gets silent too. When they cross the road and reach the rushing stream, Doniyor suddenly slows down the chariot, whips the horses, and starts to sing with a trembling voice.

Doniyor's singing also makes it clear that there is some charm and pain in the way he was singing. The author describes his situation from the Seit's words: "Is this the voice of the singer or something else that comes from the heart? What is it that touches the most delicate strings of a man's heart and gives him good intentions? Honestly, I can't even answer that question right now.'"[8], [94].

There were almost no words in this song, but the song was expressing all the joy, hopes, and wishes of the sincerest and sincere heart even without the words. Seit can't understand Doniyor. But it was clear that this day, as he had long been looking forward to, Doniyor was pouring out his entire secret. Doniyor sings so great that it feels like as if his song is stirring up over the night field and awakening the sleeping field. Yes, it was the first step of two hearts to wake up. And the name of this awakening was love. From that day on, something will change in their lives.

Yes, it was a song about great love. In it there was a harmony of human love, spiritual and moral needs, and longing for the motherland, parents, friends, children, life, the world, and all goodness. The mystery of the song of Doniyor was that it made all the above images vivid in the listener's heart. Seit saw this as the reason for Doniyor's long-awaited and joyful time when he had been wandering abroad for many years, eager to see his country. For the man knew that with so much love and longing for his homeland, the sun of love and affection would shine in his heart.

Perhaps, it was at that time that his soulful songs about his motherland were born. As he listens to Doniyor's songs, he realizes why a human being loves his motherland so much that he bows down and hugs and kisses her as if she were his own mother. This was the first time that he had experienced such a feeling in his heart. He is now burning with the strong desire that if he can feel and love the sacredness of his native soil, as well as the beauty, He can sing her hymn as Doniyor.

Because of these events, the work reaches its climax. Now a new, completely different world opens up in the heroes' inner world. After that, Jamila was radically changed. The former cheerful, joking, and eloquent bride just fades away. Her playful eyes now look as sad as the sun on a cloudy day. It is no wonder as it was bearing the question of as to whether the sun could drive away the cloud blocking her path from her eyes. As they were going along the road Jamila was deep in thought and she was wearing a light barely noticeable smile. But it seemed that she was enjoying something delicately known to her only, and rejoicing in it. She was as if burning in two bonfires, and she knew what the other bonfire was and felt anxious as if she knew what was to come.
"Sometimes, on the contrary, he would shake the sack from his cart to his shoulder and stay there, as if his mind had broken something. He was like a man who, in his standing, was confronted with raging water and was amazed that he could not pass it. [9]" The author here adheres to his own style and describes the situation on the basis of a particular image. Though Jamila's sanity ordered her not to go through this water, her heart was leading her to this storm. Jamila takes Doniyor's shirt to the channel to wash and then hangs it to dry as she wipes the wrinkles. At this moment, she strokes the shirt for a long time, unknowingly. The plot of the story becomes even more acute in the process of Jamila's joke with the young men. Doniyor looked at the young men as if he was going to chew them out, and it was as if he was going to run in no time to free Jamila out of their hands.

Hidden aspiration lying in both hearts for many years was now revealing itself in its true full form overcoming any kinds of obstacles and embarrassment. A magical power led Jamila to Doniyor. After all, he wasn't the guy of yesterday. Now he was singing with such a heart that he could not understand what was going on. With her heart pounding and relaxing, Jamila would never notice her hand reaching out involuntarily. Daniel would not notice it ...

The love that Jamila and Doniyor had in their hearts was so pure and so fresh that they could hardly put it out of their bodies, they had no way other than to endure its pleasure and suffers and to obey it unconditionally. Even little Seit, who was impressed by these happy moments, thought for a moment that "It would be great if Jamila were in love with Doniyor." However, the thought that she was a bride and she was his brother's wife and it was awkward and troubling. Seit looks at Jamila's face which was growing more beautiful and more refined, and flashing of light, and although he could not realize how pure, decent and imaginative she is in her heart, and that love is a powerful force that leads man to dreams and prospects, he could sense the wake-up in these two bodies with his little heart, he watches them with surprise and joy at times.

It was so beautiful and charming that Seit's brain, influenced by Doniyor's songs, got an idea "I'll draw their picture!" - he thought and felt ecstatic as if he had found something unique. Although initially fearful of his own thinking as he thought as the whether "Can I do this or not?" the desire overcame his fears and decided, "Yes, of course, I draw their picture, and I portray them as happy as they are now!" Doniyor's song suddenly stopped as Seit was in the midst of such beautiful thoughts. It all happens in an instant, and Jamila unconsciously hugs and embraces Doniyor, then she jumps off the chariot as if something frightened her. Jamila stays up in the middle of the road facing backwards, she says to Seit, crying, "Why are you looking? What thing of yours is with me? Do not look at me; drive your cart and go!" Then she turns to Daniel 
and says, "Well, and you, why are you standing like a $\log$, drive your carriage! What a disaster that you have happened to be to me!" The words of impatient sigh of relief indicated how much her heart was suffering and burning between the boundaries of voluntariness and involuntariness.

Finally, we get closer to the events that are the culmination of the work. Here, for a moment, we will turn to the turning points of A. Kadiri's novel "Mehrobdan chayon". These two points show the courage and determination of two heroines Rano and Jamila to admire their beloved. We understand that A. Kadyri did not call this chapter a "brave girl" for nothing.

Ra'no, who had been engaged to the Khan of Kokand against her dreams, love, desires, and pleasure, was helpless in the face of this tyranny for a moment. Anvar, who worked as Khan's palace as an officer, was totally helpless. Unfortunately, such events are very common in the history of humanity and in the life of the peoples of the East. In many of these, the lovers surrendered in the face of fate. For the first time Abdulla Kadyri had set fire to the charcoal in the heart of Kumush in the heart of the Ra'no, and with the brutality of the girl, he undertakes this risky task and destroys the "millennium wall."

Ra'no sends a letter to Anvar through the trustees, and the burden of the letter was very heavy: "... Who would think that it is a noble deed of yours to be influenced from the bottom of your heart to the little thing in the darkest moments? You cannot be blamed for failing to save the life of an unfortunate girl; but is it written in the legends or credited in there that when unhappy Ra'no is under threat, when today or tomorrow is going to be a tragic day for her, should her loyal companion? Don't worry about having such a great blame, my dear Anvar. If you yearn for forgiveness of these sins, you should do one thing, and the easiest service for you: Come to us tomorrow, Wednesday, if you wish openly, or if you do not wish secretly, and say your last words to me. For, where you point the light, Ra'no is going to see her end"[10], [97].

As Kadiri wrote, this letter from Ra'no was a concern for Anvar. It made no sense to approach her, but instead he saw the burning of the heart and the renewal of the wounds. He felt no sign of goodness in the action, realized how devastating it was, and even when he met Ra'no he could see nothing but tears and frustration. But the not visiting her would also not be good for worth of the long-years love and the dignity of the young man. Therefore, Anvar was determined to meet Rano no matter how challenging the situation was. During the meeting Anvar, who decided to quit his job as a head of officers and to leave Kokand completely, was addressed with unexpected courage by Ra'no saying: "- Would you not... Would you not take me with yourself?" The words of Ra'no was responded by Anvar as, " - Would it be ... Would it be possible for you, Ra'no?". And Ra'no replies with trembling voice saying "possible"..." [11], [258].
Anvar was taken back from the unexpected suggestion, and he thinks to himself that she was a "brave girl". Indeed, this was the first time for women to act rebellious towards the animalistic manner of Khudayarkhan. Despite consciously expecting how hard and dangerous it was going to be in the future, Anvar embraces the bravery listening to his heart's decision.

Let us go back to the plot when Jamila and Doniyor were in the same predicament. For some reason, it is not a good thing for Jamila to receive a letter from a colleague who met her husband Sodik in one of Saratov's hospitals which does not cause her happiness.

"Jamila hurriedly took the letter, blushing at first, whether she was excited or ashamed, and then turned pale and silently looked at Doniyor. $\mathrm{He}$ stretched his legs like in the storage house, and stood alone near his chariot, looking sad at Jamila. "[12], [264].

This melancholy would mean the defenselessness of love in the face of impossibility; it would mean that the love had no other options than to surrender. The reason is that Jamila was the wife of a soldier who had been fighting walking over the blood in the war. That was the side which was putting Doniyor's heart in fire. Yet, he did not know how to cross the border of impossibility. It is then that the "brave woman" Jamila, by her courage and dare, crossed that border destructively. Because she had the right to live happily, just as Ra'no, who said "I won't sleep in the dirty bed of Khan", did. According to the literary researcher Kh. Lutfiddinova, "This breviary is the breviary that destructed the slavery, dependency, helplessness, instability, coward and jailbird chains which have been living in the spirituality of Uzbek girls and women" [13], [105]. Ch.Aitmatov defines the courage of Jamila in this term as follows:

"- Doniyor, here I am, I have come myself! She said whispering.

The surrounding is as silent as a grave; a bolt of lightning strikes the sky causing a horrific thunderclap.

-Have you been upset? Are you feeling

The silence took place again, the soil near the bank of water plopped as it dropped into water.

Lightning boomed over the mountains. When Jamila glanced frightenedly, the light shone on her face. Jamila looked around and threw herself into Doniyor's chest; her shoulders were trembling under Doniyor's strong hands ..." [14], [9].

In this case as well, Ch.Aitmetov describes the inner rebellions and uprisings of heroes in harmony with natural phenomena in accordance with his artistic style and skills. Yes, "the bank plopped, the lightning boomed over a millennium old mountains". We can see the extreme example of that in exactly the aforementioned situation. The courage of Jamila 
injected power into Doniyor who had completely lost himself in the world of hopelessness:

"I have always loved you. Even though I had never seen you before, I constantly thought of you in lying down in the trench. I knew that my loved one was in my homeland. This was you, My Jamila" [15], [106]. This is how the writer describes such a subsequent situation. "There came rain then. The black canvas covering the roof of the black house flew in the wind like a winged bird. Sometimes the sloping, sometimes vertically rain poured down upon the soil kissing as if it was waiting for the soil. It was as if a series of thunderstorms roared and the whole sky swept through. The mountains so far away looked as red as spring tulips" [16], [107]. The writer describes this hope reborn in Doniyor's heart that beautifully. This hope led them to new life. Seit says goodbye not only to Jamila and Doniyor, but also to his childhood. The next day, rumors spread in the aul. Everyone condemns Jamila.

In the aul, it was only Seit who did not condemn Jamila for her escape with Doniyor, and found her right. He believed that Jamila and Doniyor, a high-hearted man, had found their true happiness. He did not feel sympathetic for his brother at all, but he did feel pity on his mother. After that, the mother felt very vulnerable and lost all her power. A mother, whose understanding of a task for a married women to be lifelong commitment to a husband in married life, was not able to understand that the flow of life which is cruelly engrossed in the old roots and pursued with new happiness. Sodik, who came from the military, was not feeling furious for the loss of love, and the beloved wife, but for the sake of manly hanor. The manly honor, yes, he had stolen Jamila because of this desire, not asking for her consent or agreement and not counting on her dreams. So when he drank, he would say, "It is a bastard that has gone! She will wander around and die of hunger sooner or later. The world is full of wives; one can choose the best one among many. A frog-headed husband is far better than a golden-headed wife!"

One day, while Seit was painting a picture at his house, the door suddenly opens, and his brother Sodik, whose eyes were pale and bloody with anger, comes into the house. "Did you draw it?" he showed him a piece of paper with anger. It was a picture of Doniyor and Jamila sitting on the storage house painted in a pencil. When his brother heard him say, "Yes, I drew it," he said, "Oh, you betrayer!" he tore the picture into pieces, tucked it under his feet, and then closed the door hard as he went out.

The mother asks Seit "Did you know it?" and he responds saying "Yes, I did!" As Seit looks at the torn picture lying down on the ground, he cannot bear with the humiliation nailing him in his heart: "Fine, I am a "traitor" to our family and tribe, but I have not betrayed on humanity, the truth and the honesty of life. In contrast, I have been on the side of justice..." [17],
[111]. Unfortunately, Neither people nor even his own mom could understand such emotions and situation.

It was a triumph of happiness over old habits and beliefs that undermined the unhappiness, the gloom, and the right to love.

As we mentioned at the outset, Chingiz Aitmatov did not name this story as "Jamila" for no reason. Jamila is a beauty, and this work is a symbol of true beauty. In fact, the names Jamil and Jamila are most common in the countries of the East. Often, our scholars say comforting words, "فَصَنْرُ جَمِيِل (May the Almighty bless you with a beautiful patience)" when consoling families. Apparently, the words "jamil" and "jamila" do not only mean the physical beauty, but also the beauty, inner beauty of the person, the light and the pleasure that comes from endurance and patience. From this it can be said that this work is primarily the work of the beauty of the hearts of those who have overcome the darkness and ignorance by the sun of love.

When a person has a big heart, it can include the homeland, the creation, all the good, and he looks everything lovingly ... Maybe, that is what drew Louis Aragon's attention? In this sense, this work was a modern interpretation of Oriental love based on the poems "Tohir and Zuhra", "Layli and Majnun", "Farhad and Shirin". The reason of this was that there is no lust, nor passion towards intercourse, but purity, freshness, spiritual harmony, pure bliss, and perfection. It was the love of the author's dream. The reason was that he grew up influenced by such love stories. Now his only goal was to bring it closer to the heart of the world, this was a modern interpretation of Oriental love that was elevated by the will to beauty.

Seit in "Jamila" is the author himself. First of all, the author is in love with this beauty. Seit draws a picture of pure love in his eyes, which he wants to show the world. It was an image of happiness, of happy ending. The child is insulted for not telling although he knew it, in fact, the insults were aimed at the author himself. The author knew that they would blame him, just as they blamed the child.

What is life? Why does man come into this world? Does a person have the right to love and be loved? In a forced way of life, Jamila's words seemed to light up, but her heart was still in the dark. In this compulsory way of life, she was looking for a bunch of light. In Doniyor she saw the true life, the beauty of the heart, the world that she longed for and desired. At first, she humiliated Doniyor and laughed at him. Then, the beauty of Jamila's heart surrendered to the sun, which burst through the black clouds, and she rushed to Doniyor. Jamila was abducted against her wishes and dreams. She had the right to live as she pleased, to love whomever she wanted. Unlike Jamila's predecessors, she did not admit what was in her fate saying "C'est la vie". She fought for life, struggled for her dreams, and love. Jamila and Sodik, the couple did not have a sacred marriage in their essence. The author does not refer to marriage anywhere. On the contrary, the essence of this captive life was cruelty and ignorance. 
If Sodik was a symbol of ignorance, Jamila was a symbol of freedom that penetrated the veil of ignorance.

Chingiz Aitmatov brings Jamila to the world, palace of love from the paws of cruel fate. He gives her the love, the happiness of love, the happiness of living as a human being. Needless to say, the marriage of Jamila and Daniel is "organized" by the author himself.

Remember, there is such a passage in the work. Seit can never forget the scene of Doniyor and Jamila sitting next to each other on the chariot. In the end, he stole a thick sheet of paper of the accountant from the storage house, and hides behind the stack, put it on a grain-cutting shovel, and began to portray them with excitement. The author writes the scene as follows: "I said "Bismilloh" as my father said when putting me on the horse for the first time, and let the pencil touch the paper."

Note that the boy, that is, Seit, started painting by saying "bismillah", in other words, "in the name of Allah." Seit seems to have wedded two sweethearts and wished them a new way of life... Although it was not allowed to use the word in the literature works at the times of Soviet regime, Chingiz Aitmatov firmly says the sacred word. The writer here refers to the great value. In the name of Allah, he gives his heroes the right to live and love and to be happy, and to guide them in this life.

"Jamila" is a work that glorifies the love and right to live within the hearts condemned to exist, ignorant of the existing traditions, which are created against the wishes of human beings, especially girls. Yes, every soul has the right to love, to be loved, to marry, to build a family according to the will and hope of the two souls. Many scholars and ordinary readers describe this rebellion in the nature of Jamila as contrary to the Oriental mentality and values.

\section{CONCLUSION}

According to the teachings of Sacred Islam, Islam forbade man to marry women when they did not request or permit it. So it is rebellion against ignorance, not religious values. That is why, we fall in love with Jamila, approve of her struggle for happiness, and the only reason we admire her is the voice that applauds Jamila deep in our hearts. This is the right of the hearts.

"Behold, the sun was rising up from the mountain, and the lonely sunflower on the ditch was reaching out to it. It was surrounded by crows, but the sunflower was eager to go to heaven, with its yellow flowery heads proudly absorbing the sun rays." It is the embodiment of the courage and love that captivated us, the triumph of the human will, the human heart and love that did not obey the fate of destiny.

From the analysis it can be concluded that Jamila, the courageous woman who has taken the first step in this regard, who is determined to change her destiny for love and happiness, is the symbol of elegance - Ra'no's counselor sister.
Chingiz Aitmatov's Jamila also has the courage to embrace the beautiful love as Abdullah Kadiri's Ra'no. After all, it was a poem about the illuminated souls who, in the hope of self-realization, sought love, happiness, conquered ignorance, and surrendered before beauty.

\section{REFERENCES}

1. И.Султон. Суззбоши Мехробдан чаён, Т. 1982., 4 б. (I.Sulton. Foreword for Mehrobdan chayon, T.1982., $p$ 4.)

2. А.Мелибоев. Чингиз Айтматов: Давр. Инсон. Хақ̧иқ̆ат. Т.: Г.Ғулом номидаги нашриётижодий матбаа уйи, 2018. Б.56. (Meliboev A. Chingiz Aitmatov: Time. Human. Truth. T.: publishing house named after G.Gulom, 2018. P 56.)

3. Ч. Айтматов. Жамила / Танланган асарлар. Т.: "Шарку" нашриёт-матбаа акциядорлик компанияси Бош тахририяти, 2018. Б. 79. (Ch. Aitmatov. Jamila / Selected works. T.: "Sharq" publishing stock-company Head editorial, 2018. P.79.)

4. The same work. P. 79.

5. The same work. P. 81 .

6. The same work. P. 82.

7. The same work. P.85.

8. The same work. P. 94.

9. The same work.

10. The same work. P. 97.

11. Абдулла Қодирий. Мехробдан чаён. Т.: Янги аср авлоди, 2017. Б. 258. (Abdulla Kadyri. Mehrobdan chayon. T.: Yangi asr avlodi, 2017. P. 258)

12. The same work. P. 264.

13. Ч.Айтматов. Жамила / Танланган асарлар. Т.: “Шарк̧” нашриёт-матбаа акциядорлик компанияси Бош тахририяти, 2018. Б. 105. (Ch. Aitmatov. Jamila / Selected works. T.: "Sharq" publishing stock-company Head editorial, 2018. P.105.)

14. Х.Лутфиддинова. Гулларнинг Раъноси. Т.: Ўзбекистон, 1997. Б. 9. (Lutfiddinova Kh. The Ra'no of Flowers. T.: Uzbekistan, 1997. P. 9.)

15. Ч. Айтматов Жамила / Танланган асарлар. Т.: “Шарқ ” нашриёт-матбаа акииядорлик компанияси Бош тахририяти, 2018. Б. 106. (Ch. Aitmatov. Jamila / Selected works. T.: "Sharq" publishing stock-company Head editorial, 2018. P.106.)

16. The same work. P. 107.

17. The same work. P. 111. 